\title{
AKSESIBILITAS MAHASISWA KESEHATAN DAN MAHASISWA NON KESEHATAN STRATA S-1 UNIVERSITAS AIRLANGGA TERHADAP PROGRAM JAMINAN KESEHATAN NASIONAL
}

\author{
Accessibility on Health Students and Non Health Students Levels S-1 Universitas Airlangga towards \\ National Health Security \\ Ulfia Hazna Safira' ${ }^{1}$, Djazuly Chalidyanto ${ }^{2}$ \\ ${ }^{1}$ Ikatan Ahli Kesehatan Masyarakat Jawa Timur, Indonesia \\ 2Departemen Administrasi dan Kebijakan Kesehatan, Fakultas Kesehatan Masyarakat, Universitas Airlangga, \\ Indonesia \\ E-mail: ulfia_hazna@yahoo.co.id
}

\begin{abstract}
The participant of National Health Security in October 2016 still reached $66.11 \%$ of population. Public and students knowledge about benefits and uses of National Health Security still low. The lack of knowledge, used, and community participation showed the lack of community accessibility in National Health Security program. Students as agents of change are expected to make National Health Security success The objectives of this research was to analyze the differences of health student's accessibility and non-health student's accessibility to National Health Security program. The method of this research used online questionnaire with analytic type of research used observational research and cross sectional design. The results showed there were differences of accessibility between health students and non-health students based on knowledge aspect, proximity of health facility that accept National Health Security, perception of the importance of National Health Security, National Health Security participants, utilization of National Health Security, ease of National Health Security used, affordability of National Health Security, and satisfaction of National Health Security. Meanwhile health students accessibility with non-health students did not have differences on ease of gets information aspect, accommodation availability, and perception of the accuracy of National Health Security program.
\end{abstract}

Keywords: accessibility, national health security, students

\section{ABSTRAK}

Kepesertaan JKN sampai dengan Oktober 2016 masih mencapai 66,11\% dari jumlah keseluruhan jumlah penduduk. Pengetahuan publik maupun mahasiswa tentang JKN juga masih rendah. Rendahnya pengetahuan, pemanfaatan dan kepesertaan menunjukkan rendahnya aksesibilitas masyarakat terhadap JKN. Mahasiswa sebagai agen perubahan diharapkan dapat mewujudkan keberhasilan JKN. Tujuan dari penelitian ini adalah untuk menganalisis perbedaan aksesibilitas mahasiswa kesehatan dan mahasiswa non kesehatan terhadap program JKN. Metode penelitian ini menggunakan kuesioner online dengan jenis penelitian analitik dengan rancang bangun observasional dan desain penelitian cross sectional. Hasilnya terdapat perbedaan aksesibilitas antara kelompok mahasiswa kesehatan dengan mahasiswa non kesehatan berdasarkan aspek pengetahuan, kedekatan fasilitas kesehatan yang menerima JKN, persepsi pentingnya JKN, kepesertaan JKN, pemanfaatan JKN, kemudahan penggunaan JKN, keterjangkauan JKN, dan kepuasan JKN. Sedangkan aksesibilitas mahasiswa kesehatan dengan mahasiswa non kesehatan tidak memiliki perbedaan pada aspek kemudahan memperoleh informasi, ketersediaan akomodasi dan persepsi ketepatan program JKN.

Kata Kunci: aksesibilitas, JKN, mahasiswa

\section{PENDAHULUAN}

Kesehatan merupakan kebutuhan dasar setiap manusia dan merupakan investasi berharga dalam membangun bangsa. Peningkatan derajat kesehatan masyarakat membutuhkan komitmen yang kuat dari pemerintah terkait sistem kesehatan nasional. Salah satu bukti nyata yang dilakukan pemerintah sebagai upaya peningkatan derajat kesehatan masyarakat yakni dengan meluncurkan program Jaminan Kesehatan Nasional (JKN). Pada tanggal 1
Januari 2014, penyelenggaraan JKN resmi dimulai. JKN merupakan bagian dari Sistem Jaminan Sosial Nasional (SJSN) dengan kepesertaan yang bersifat wajib (mandatory).

Walaupun sifat kepesertaan JKN wajib, belum seluruh lapisan masyarakat telah menjadi peserta program JKN. Sampai dengan Oktober 2016 tercatat jumlah peserta JKN sebesar 169,5 juta jiwa atau kurang lebih $66,11 \%$ dari total penduduk tahun 2016 sebesar 256,5 juta jiwa (BPJS Kesehatan, 2017). Bahkan, pengetahuan masyarakat terhadap JKN 
masih rendah (baik yang belum menjadi peserta maupun yang sudah terdaftar menjadi peserta) (Amalina, et al., 2015). Rendahnya pengetahuan masyarakat terkait JKN, menunjukkan bahwa masih minimnya informasi yang diterima masyarakat terkait JKN. Sementara itu berdasarkan penelitian yang dilakukan oleh Dimantri (2017), menyatakan bahwa pengetahuan mahasiswa Fakultas Kesehatan Masyarakat Universitas Airlangga didominasi pada kategori cukup yakni $69,4 \%$. Tingkat pengetahuan ini terkait pengertian JKN, badan yang bertanggung jawab terhadap JKN, peraturan terkait pelaksanaan $\mathrm{JKN}$, proses pemanfaatan JKN, besaran iuran JKN dan jenis pelayanan yang ditanggung JKN. Selain itu, berdasarkan penelitian yang dilakukan Dimantri (2013), niat mahasiswa untuk menjadi peserta program JKN yakni 46,7\% kategori baik, 43\% kategori buruk dan 10,3\% sisanya pada kategori cukup. Meskipun didominasi oleh niat dengan kategori baik, namun hanya selisih 3,7\% jika dibandingkan dengan penilaian niat dengan kategori buruk. Penilaian niat tersebut meliputi niat mahasiswa untuk menjadi peserta JKN dan niat mahasiswa untuk mengajak keluarga atau orang terdekat untuk menjadi peserta JKN. Dari penjelasan tersebut dapat menggambarkan bahwa tingkat kepesertaan JKN, pengetahuan terkait JKN dan niat menjadi peserta JKN masih belum optimal. Selain itu menurut penelitian yang dilakukan oleh Rahmawati (2016), pelaksanaan jaminan kesehatan masih diragukan karena menurut sebagian masyarakat, JKN kurang memihak kepada rakyat. Oleh sebab itu perlu diketahui aksesibilitas masyarakat terhadap program JKN sebagai upaya pemerataan pelaksanaan JKN. Aksesibilitas memiliki hubungan dengan tingkat pemanfaatan pelayanan kesehatan (Masita et al., 2015). Aksesibilitas merupakan kemampuan seseorang untuk mencari dan mendapatkan sesuatu yang mereka inginkan atau mereka butuhkan (Laksono et al., 2016).

Aksesibilitas terhadap program JKN merupakan hal yang sangat penting dan dapat memengaruhi kesuksesan program JKN di masa yang akan datang. Semakin baik aksesibilitas masyarakat terhadap program JKN, maka masyarakat semakin lebih terlindungi akan kebutuhan kesehatannya. Namun sebaliknya, jika aksesibilitas masyarakat terhadap program JKN buruk, maka upaya perlindungan kesehatan masyarakat akan semakin sulit. Hal tersebut menggambarkan bahwa aksesibilitas masyarakat mampu memengaruhi kesuksesan JKN.

Mahasiswa merupakan salah satu kelompok masyarakat yang dikenal sebagai kelompok intelektual. Selain itu mahasiswa merupakan agent of change (agen perubahan) yang diharapkan mampu meningkatkan kesejahteraan bangsa di masa yang akan datang. Sebagai salah satu kelompok masyarakat, mahasiswa juga memiliki kewajiban untuk menjadi peserta JKN. Tidak hanya itu, mahasiswa berperan penting dalam menyukseskan program JKN mengingat mereka adalah generasi penerus bangsa. Dalam mewujudkan universal health coverage, BPJS Kesehatan melakukan kerja sama dengan Kementerian Riset, Teknologi dan Pendidikan Tinggi sebagai upaya perluasan cakupan kepesertaan (BPJS Kesehatan, 2017). Hal tersebut menunjukkan bahwa terdapat harapan besar pemerintah kepada mahasiswa dalam mencapai kesuksesan program JKN. Aksesibilitas mahasiswa terhadap program JKN saat ini akan memengaruhi keberlanjutan program JKN di waktu yang akan datang. Aksesibilitas dapat dipengaruhi oleh Approachability (Kedekatan), Acceptability (Penerimaan), Availability (Ketersediaan dan Transportasi), Affordability (Keterjangkauan) dan Appropriateness (Ketepatan) (Levesque et al., 2013).

Untuk mengetahui aksesibilitas JKN pada mahasiswa, perlu adanya analisis aksesibilitas JKN baik pada mahasiswa bidang kesehatan dan mahasiswa bidang non kesehatan. Pengelompokan mahasiswa ini dibentuk agar terlihat perbedaan antara aksesibilitas mahasiswa kesehatan (yang mendapatkan ilmu pengetahuan yang lebih dekat dengan JKN serta memiliki tanggung jawab lebih terhadap program JKN) dan mahasiswa non kesehatan (yang memiliki latar belakang studi yang berlawanan dengan program JKN). Mahasiswa yang dipilih adalah mahasiswa Strata 1. Pemilihan mahasiswa Strata 1 dilakukan dengan alasan yaitu jumlah mahasiswa maupun lulusan strata 1 merupakan jumlah lulusan terbanyak pada setiap tahunnya jika dibandingkan dengan strata 2 ataupun strata 3 (Kementerian Pendidikan dan Kebudayaan , 2015). Dari pernyataan tersebut menunjukkan bahwa sebagian besar mahasiswa dalam kampus merupakan mahasiswa strata 1 , sehingga dominas tersebut dijadikan kriteria penelitian dengan tujuan agar penelitian ini mampu menggambarkan kondisi sebenarnya dengan diwakili oleh golongan terbesar mahasiswa. Tujuan dalam penelitian ini adalah untuk menggambarkan aksesibilitas mahasiswa kesehatan dan mahasiswa non kesehatan terhadap program JKN. Sedangkan manfaat dari penelitian ini yaitu agar kita dapat mengetahui perbedaan aksesibilitas mahasiswa kesehatan dan mahasiwa non kesehatan terhadap program JKN

\section{METODE}

Penelitian ini merupakan jenis penelitian analitik dengan rancang bangun observasiona dan desain penelitian cross sectional yakni dengan pengambilan data satu waktu tertentu. Pengambilan data dilakukan dengan kuesioner online dengan indikator menurut Levesque dkk (2013) yang dibuka mulai tanggal 28 April 2017 hingga 2 Mei 2017. Kuesioner online ini ditujukan kepada mahasiswa aktif strata S-1 Universitas Airlangga. Populasi dalam penelitian ini adalah seluruh mahasiswa strata I Universitas Airlangga. Cara pengambilan sampel dengan purposive sampling. Teknik pengambilan sampel yakni dengan teknik self selection yaitu para pengguna internet yang mengetahui riset ini yang dapat berpartisipasi dalam riset. Ukuran sampel dalam statistik minimal sebesar 30 responden. Sedangkan jika menggunakan toleransi kesalahan $10 \%$, dibutuhkan 100 orang responden (tingkat kepercayaan 90\%) (Sarwono, 2017). Kriteria inklusi dari penelitian ini yaitu merupakan mahasiswa aktif dan merupakan mahasiswa 
Strata 1 Universitas Airlangga. Analisis hasil data kuesioner online dilakukan dengan menggunakan uji $T$ sampel bebas untuk mengetahui perbedaan aksesibilitas mahasiswa kesehatan dan mahasiswa non kesehatan program S-1 Universitas Airlangga. Mahasiswa kesehatan terdiri dari mahasiswa Fakultas Kedokteran, Kedokteran Gigi, Kesehatan Masyarakat, Farmasi dan Fakultas Keperawatan. Sedangkan mahasiswa non kesehatan terdiri dari mahasiswa Fakultas Kedokteran Hewan, Sains dan Teknologi, Perikanan dan Kelautan, Ekonomi Bisnis, Psikologi, IImu Budaya, Hukum, IImu Sosial dan IImu Politik, serta Fakultas Hukum. Faktor yang digunakan untuk penilaian aksesibilitas mahasiswa dalam penilaian ini meliputi Approachability (Kedekatan), Acceptability (Penerimaan), Availability (Ketersediaan dan Transportasi), Affordability (Keterjangkauan) dan Appropriateness (Ketepatan) (Levesque et al., 2013).

\section{HASIL DAN PEMBAHASAN}

\section{Karakteristik Responden}

Analisis ini dilakukan pada 232 responden. Keseluruhan jumlah responden tersebut digolongkan menjadi dua kelompok yaitu mahasiswa kesehatan dan mahasiswa non kesehatan. Dari jumlah keseluruhan responden tersebut sebanyak 138 responden adalah mahasiswa kesehatan, dan 94 responden sisanya adalah mahasiswa non kesehatan.

Berdasarkan karakteristik responden diketahui pada kelompok mahasiswa kesehatan yang berjenis kelamin laki-laki sebanyak $13 \%$ dan sisanya $87 \%$ adalah perempuan. Hampir sama dengan kelompok mahasiswa non kesehatan yakni mahasiswa berjenis kelamin laki-laki sebesar $30 \%$ dan perempuan sejumlah $70 \%$. Sedangkan terkait umur responden pada kedua kelompok mahasiswa ini memiliki kesamaan yakni umur terbanyak ada pada kisaran umur 21-23 tahun dan umur yang paling sedikit yakni $>23$ tahun. Sedangkan pada kedua kelompok ini, jenis pekerjaan orang tua terbanyak yakni pada pekerjaan PNS dan paling sedikit pada pekerjaan buruh bagi kelompok mahasiswa kesehatan, dan pegawai pemerintahan non PNS bagi kelompok mahasiswa non kesehatan.

Selain itu pada kelompok mahasiswa kesehatan terdapat $13 \%$ adalah laki-laki, dan $87 \%$ sisanya adalah perempuan. Sedangkan pada kelompok mahasiswa non kesehatan, $30 \%$ adalah laki-laki dan $70 \%$ sisanya adalah perempuan. Sementara itu terkait umur responden, pada kelompok mahasiswa kesehatan, umur responden terbanyak pada kisaran umur 21-23 tahun (61\%), umur 18-20 tahun sebanyak $38 \%$ dan yang paling sedikit adalah kisaran umur $>23$ tahun yakni sebesar $1 \%$. Tingkatan besaran jumlah responden menurut umur tersebut hampir sama dengan responden kelompok mahasiswa non kesehatan yakni kelompok umur tertinggi ada pada kisaran umur 21-23 tahun sebesar 57\%, kemudian kisaran umur 18-20 tahun sebesar $40 \%$ dan yang paling sedikit adalah responden dengan kisaran umur $>23$ tahun sebanyak $3 \%$. Sedangkan pada jenis pekerjaan orang tua, pada kelompok mahasiswa kesehatan, jenis pekerjaan orang tua tertinggi terdapat pada PNS sebanyak $44 \%$, swasta sebanyak $21 \%$, wiraswasta sebanyak $15 \%$, pegawai pemerintahan Non PNS sebanyak $8 \%$, petani sebanyak $6 \%$, pensiunan sebanyak $4 \%$, dan yang paling rendah adalah buruh sebanyak $2 \%$. Berbeda halnya dengan kelompok mahasiswa non kesehatan, jenis pekerjaan orang tua tertinggi secara berurutan yaitu PNS sebesar $27 \%$, Wiraswasta sebesar $25 \%$, Swasta sebesar 23\%, Buruh sebesar 10\%, Pensiunan sebesar $7 \%$, Petani sebesar $6 \%$, dan yang paling rendah adalah Pegawai Pemerintahan Non PNS sebesar $2 \%$.

\section{Analisis Faktor Aksesibilitas}

Analisis dilakukan dengan menggunakan lima faktor aksesibilitas menurut Levesque, Jean dan Mark (2013) yaitu Approachability (Kedekatan), Acceptability (Penerimaan), Availability (Ketersediaan dan Transportasi), Affordability (Keterjangkauan) dan Appropriateness (Ketepatan). Berikut hasil analisis pada setiap faktor.

Berdasarkan Tabel 1, dapat diketahui bahwa hasil penilaian aksesibilitas pada kedua kelompok mahasiswa. Variabel pertama yakni Approachability (kedekatan). Variabel ini meliputi indikator pengetahuan mengenai program JKN (pengertian $\mathrm{JKN}$, prinsip JKN, manfaat JKN) sulit atau tidaknya mendapatkan informasi terkait program JKN, dan ada tidaknya fasilitas kesehatan yang menerima layanan JKN di daerah tempat tinggal. Berdasarkan Tabel 1, menunjukkan bahwa terdapat perbedaan antara pengetahuan kelompok mahasiswa kesehatan dan kelompok mahasiswa non kesehatan mengenai JKN. Pada kelompok mahasiswa kesehatan, yang memiliki pengetahuan baik sebesar $72 \%$ dan yang memiliki pengetahuan kurang sebesar $28 \%$. Sedangkan pada kelompok mahasiswa non kesehatan, yang memiliki pengetahuan yang baik sebesar $52 \%$ dan yang memiliki pengetahuan yang kurang baik sebesar $48 \%$.

Sebagai kelompok mahasiswa kesehatan yang tentunya mendapat pelajaran terkait JKN, seharusnya lebih mengerti dan memahami JKN. Pelajaran yang dimaksud antara lain yaitu administrasi kebijakan dan kesehatan, ekonomi kesehatan serta sistem pembiayaan dan asuransi kesehatan. Meskipun secara umum kelompok kesehatan memiliki pengetahuan yang lebih baik, namun pada kelompok kesehatan masih ada responden yang tidak mengerti dan memahami JKN. Sedangkan pada mahasiswa non kesehatan, sebagian besar memiliki pengetahuan yang kurang terkait JKN. Sementara itu, berdasarkan penelitian yang dilakukan oleh Cahyani (2015), tingkat pengetahuan masyarakat masih rendah dan tidak sesuai dengan harapan BPJS. Masyarakat telah memiliki sikap positif terhadap program JKN, namun ketertarikan masyarakat rendah pada faktor bukti manfaat (Cahyani, 2015). Hal ini menggambarkan bahwa tingkat pengetahuan masyarakat terhadap program JKN mampu memengaruhi ketertarikan masyarakat terkait JKN.

Jika penilaian variabel pengetahuan tersebut dilakukan tabulasi silang dengan variabel kemudahan 
Tabel 1. Persentase Pengetahuan Mahasiswa Kesehatan dan Mahasiswa Non Kesehatan Strata S-1 Universitas Airlangga

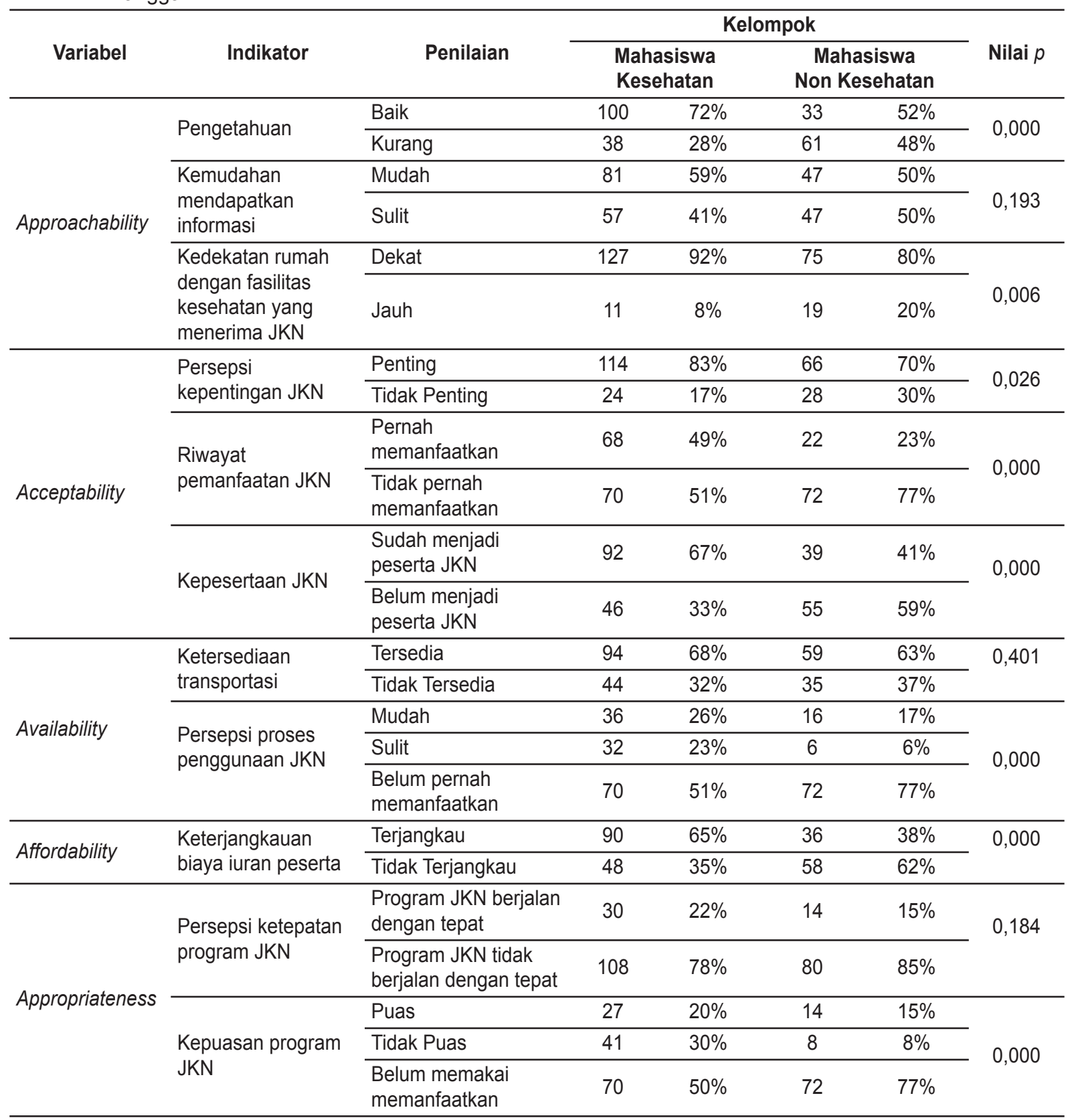

mendapatkan informasi, maka dapat diketahui bahwa pada kelompok mahasiswa kesehatan dengan pengetahuan yang baik memiliki kemudahan mendapatkan informasi sebanyak 71 mahasiswa dan kesukaran mendapatkan informasi sebanyak 29 mahasiswa, sedangkan mahasiswa kesehatan dengan pengetahuan yang kurang memiliki kemudahan mendapatkan informasi sebanyak 10 mahasiswa, dan kesukaran mendapatkan informasi sebanyak 28 mahasiswa. Sedangkan pada kelompok mahasiswa non kesehatan dengan pengetahuan yang baik memiliki kemudahan mendapatkan informasi sebanyak 29 mahasiswa dan kesukaran mendapatkan informasi sebanyak 4 mahasiswa, sedangkan mahasiswa non kesehatan dengan pengetahuan yang kurang memiliki kemudahan mendapatkan informasi sebanyak 18 mahasiswa, dan kesukaran mendapatkan informas sebanyak 43 mahasiswa

Sementara itu jika penilaian variabel pengetahuan tersebut dilakukan tabulasi silang dengan variabel kepesertaan, maka dapat diketahu bahwa pada kelompok mahasiswa kesehatan dengan pengetahuan yang baik dan sudah menjadi peserta JKN sebanyak 83 mahasiswa dan yang belum menjadi peserta JKN sebanyak 29 mahasiswa, sedangkan mahasiswa kesehatan dengan pengetahuan yang kurang dan sudah menjadi peserta JKN sebanyak 9 mahasiswa, dan yang belum menjadi peserta JKN sebanyak 29 mahasiswa. Sedangkan pada kelompok mahasiswa non kesehatan dengan pengetahuan yang baik dan sudah menjadi peserta JKN sebanyak 27 mahasiswa dan yang belum menjadi peserta JKN sebanyak 6 mahasiswa, sedangkan mahasiswa non 
kesehatan dengan pengetahuan yang kurang dan sudah menjadi peserta JKN sebanyak 12 mahasiswa, dan yang belum menjadi peserta JKN sebanyak 49 mahasiswa.

Berdasarkan Tabel 1, menunjukkan bahwa tidak terdapat perbedaan antara kemudahan mendapatkan informasi mengenai JKN pada kelompok mahasiswa kesehatan dan kelompok mahasiswa non kesehatan. Pada kelompok mahasiswa kesehatan, yang menyatakan bahwa mendapatkan informasi mengenai JKN tergolong mudah sebesar $59 \%$, sedangkan sisanya sebesar $41 \%$ menyatakan bahwa upaya mendapatkan informasi mengenai JKN tergolong sulit. Sementara itu pada kelompok mahasiswa non kesehatan, terdapat $50 \%$ responden menyatakan mendapatkan informasi mengenai JKN tergolong mudah dan $50 \%$ sisanya menyatakan dalam mendapatkan informasi mengenai JKN tergolong sulit. Hampir separuh responden pada kelompok mahasiswa kesehatan mengakui bahwa mendapatkan informasi terkait JKN tergolong sulit (41\%). Begitu pula pada kelompok mahasiswa non kesehatan. Kondisi tersebut menunjukkan bahwa akses dalam mendapatkan informasi tentang JKN pada kedua kelompok mahasiswa secara umum pada kondisi yang sama. Meskipun pada kenyataannya mahasiswa kesehatan lebih memiliki akses dalam mendapatkan informasi terkait JKN. Selain itu sumber informasi bisa didapatkan dari mata kuliah, media cetak maupun media elektronik.

Indikator ketiga adalah kedekatan rumah dengan fasilitas kesehatan yang menerima JKN Berdasarkan Tabel 1, menunjukkan bahwa terdapat perbedaan antara kedekatan rumah dengan fasilitas kesehatan yang menerima JKN pada kelompok mahasiswa kesehatan dan kelompok mahasiswa non kesehatan. Pada kelompok mahasiswa kesehatan, yang menyatakan bahwa jarak rumah dengan fasilitas kesehatan yang menerima JKN tergolong dekat sebesar $92 \%$, sedangkan sisanya sebesar $8 \%$ menyatakan bahwa jarak rumah dengan fasilitas kesehatan yang menerima JKN tergolong jauh. Sementara itu pada kelompok mahasiswa non kesehatan, terdapat $80 \%$ responden menyatakan bahwa jarak antara rumah dengan fasilitas kesehatan yang menerima JKN tergolong dekat dan 20\% sisanya menyatakan bahwa jarak antara rumah dengan fasilitas kesehatan yang menerima JKN tergolong jauh. Menurut penelitian yang dilakukan oleh Alfian (2000), aspek jarak memiliki hubungan dengan fasilitas pelayanan kesehatan. Semakin jauh jaraknya maka semakin kecil peluang masyarakat dalam memanfaatkan pelayanan kesehatan. Sebaliknya, semakin dekat dengan fasilitas pelayanan kesehatan, maka semakin besar pula peluang dalam memanfaatkan pelayanan kesehatan.

Variabel kedua adalah Acceptability (penerimaan). Faktor ini meliputi persepsi penting atau tidaknya program JKN, kepesertaan JKN dan pemanfaatan program JKN. Indikator pertama adalah persepsi kepentingan JKN. Berdasarkan Tabel 1, menunjukkan bahwa terdapat perbedaan antara persepsi kepentingan pada kelompok mahasiswa kesehatan dan kelompok mahasiswa non kesehatan. Pada kelompok mahasiswa kesehatan, yang menyatakan bahwa JKN itu penting sebesar $83 \%$, sedangkan sisanya sebesar $17 \%$ menyatakan bahwa JKN tidak penting. Sementara itu pada kelompok mahasiswa non kesehatan, terdapat $70 \%$ responden menyatakan bahwa JKN itu penting dan $20 \%$ sisanya menyatakan JKN itu tidak penting.

Adanya persepsi JKN tidak penting oleh kedua kelompok mahasiswa, tentunya dilatarbelakangi karena suatu hal. Hal tersebut diperburuk dengan adanya mahasiswa kesehatan yang lebih memiliki tanggung jawab dalam menyukseskan JKN menganggap JKN itu tidak penting. Penilaian ini menunjukkan bahwa masih rendahnya penerimaan terhadap pentingnya program JKN.

Jika penilaian kepentingan JKN tersebut dilakukan tabulasi silang dengan variabel keterjangkauan biaya, maka dapat diketahui bahwa pada kelompok mahasiswa kesehatan dengan persepsi JKN itu penting dengan biaya iuran terjangkau sebanyak 77 mahasiswa dan biaya iuran yang tidak terjangkau sebanyak 37 mahasiswa, sedangkan mahasiswa kesehatan dengan persepsi JKN itu tidak penting membuat penilaian bahwa biaya iuran terjangkau sebanyak 13 mahasiswa, dan biaya iuran yang tidak terjangkau sebanyak 11 mahasiswa. Sedangkan pada kelompok mahasiswa non kesehatan dengan persepsi JKN itu penting dengan biaya iuran terjangkau sebanyak 24 mahasiswa dan biaya iuran yang tidak terjangkau sebanyak 42 mahasiswa, sedangkan mahasiswa kesehatan dengan persepsi JKN itu tidak penting membuat penilaian bahwa biaya iuran terjangkau sebanyak 12 mahasiswa, dan biaya iuran yang tidak terjangkau sebanyak 16 mahasiswa.

Sementara itu jika penilaian kepentingan JKN tersebut dilakukan tabulasi silang dengan variable pemanfaatan, maka dapat diketahui bahwa pada kelompok mahasiswa kesehatan dengan persepsi JKN itu penting dan telah memanfaatkan sebanyak 67 mahasiswa dan yang belum memanfaatkan sebanyak 47 mahasiswa, sedangkan mahasiswa kesehatan dengan persepsi JKN itu tidak penting dan telah memanfaatkan sebanyak 1 mahasiswa, dan yang belum memanfaatkan sebanyak 23 mahasiswa. Sedangkan pada kelompok mahasiswa non kesehatan dengan persepsi JKN itu penting dan telah memanfaatkan sebanyak 22 mahasiswa dan yang belum memanfaatkan sebanyak 44 mahasiswa, sedangkan mahasiswa kesehatan dengan persepsi JKN itu tidak penting dan telah memanfaatkan sebanyak 0 mahasiswa, dan yang belum memanfaatkan sebanyak 28 mahasiswa.

Sementara itu jika penilaian kepentingan JKN tersebut dilakukan tabulasi silang dengan variable kepuasan, maka dapat diketahui bahwa pada kelompok mahasiswa kesehatan dengan persepsi JKN itu penting dan merasa puas sebanyak 27 mahasiswa dan yang tidak puas sebanyak 35 mahasiswa, sedangkan 52 mahasiswa sisanya belum memanfaatkan JKN. Sedangkan mahasiswa kesehatan dengan persepsi JKN itu tidak penting dan merasa puas sebanyak 0 mahasiswa, dan yang tidak puas sebanyak 6 mahasiswa, sedangkan 18 mahasiswa sisanya belum memanfaatkan JKN. Sedangkan pada kelompok mahasiswa non 
kesehatan dengan persepsi JKN itu penting dan merasa puas sebanyak 14 mahasiswa dan yang tidak puas sebanyak 4 mahasiswa, sedangkan 48 mahasiswa sisanya belum memanfaatkan JKN. Sedangkan mahasiswa kesehatan dengan persepsi JKN itu tidak penting dan merasa puas sebanyak 0 mahasiswa, dan yang tidak puas sebanyak 4 mahasiswa, sedangkan 24 mahasiswa sisanya belum memanfaatkan JKN.

Indikator kedua adalah riwayat pemanfaatan JKN. Berdasarkan tabel 1, terlihat bahwa terdapat perbedaan antara riwayat pemanfaatan JKN pada kelompok mahasiswa kesehatan dan kelompok mahasiswa non kesehatan. Pada kelompok mahasiswa kesehatan, yang menyatakan bahwa pernah memanfaatkan JKN sebesar $49 \%$, sedangkan sisanya sebesar $51 \%$ menyatakan bahwa belum memanfaatkan JKN. Sementara itu pada kelompok mahasiswa non kesehatan, terdapat $23 \%$ responden menyatakan pernah memanfaatkan JKN dan $77 \%$ sisanya menyatakan belum pernah memanfaatkan JKN. Dari data tersebut terlihat bahwa kelompok mahasiswa non kesehatan lebih jarang menggunakan JKN daripada mahasiswa kesehatan.

Indikator ketiga terkait kepesertaan JKN. Berdasarkan Tabel 1, menunjukkan bahwa terdapat perbedaan antara kepesertaan JKN pada kelompok mahasiswa kesehatan dan kelompok mahasiswa non kesehatan. Pada kelompok mahasiswa kesehatan, yang menyatakan telah menjadi peserta JKN sebesar $67 \%$, sedangkan sisanya sebesar $33 \%$ menyatakan belum menjadi peserta program JKN. Sementara itu pada kelompok mahasiswa non kesehatan, terdapat $41 \%$ responden menyatakan telah menjadi peserta JKN dan $59 \%$ sisanya menyatakan belum menjadi peserta JKN. Dari data tersebut dapat dilihat bahwa masih adanya mahasiswa kesehatan maupun mahasiswa non kesehatan yang belum menjadi peserta program JKN. Besaran kepesertaan JKN berhubungan secara signifikan dengan persepsi responden terhadap manfaat JKN (Widhiastuti et al., 2015). Hal ini menunjukkan bahwa terdapat kemungkinan mahasiswa yang memiliki persepsi yang kurang terhadap manfaat JKN sehingga ia belum menjadi peserta JKN.

Jika penilaian kepesertaan JKN tersebut dilakukan tabulasi silang dengan variable kepuasan, maka dapat diketahui bahwa pada kelompok mahasiswa kesehatan yang sudah menjadi peserta JKN dan merasa puas sebanyak 27 mahasiswa dan yang tidak puas sebanyak 14 mahasiswa, dimana 51 mahasiswa lainnya belum memanfaatkan. Sedangkan mahasiswa kesehatan yang belum menjadi peserta dan merasa puas sebanyak 0 mahasiswa, dan yang tidak puas sebanyak 27 mahasiswa, dimana 19 mahasiswa sisanya belum memanfaatkan. Sedangkan pada kelompok mahasiswa non kesehatan yang sudah menjadi peserta JKN dan merasa puas sebanyak 14 mahasiswa dan yang tidak puas sebanyak 6 mahasiswa, dimana 19 mahasiswa lainnya belum memanfaatkan. Sedangkan mahasiswa kesehatan yang belum menjadi peserta dan merasa puas sebanyak 0 mahasiswa, dan yang tidak puas sebanyak 2 mahasiswa, dimana 53 mahasiswa sisanya belum memanfaatkan.

Variabel ketiga yaitu Availability (ketersediaan dan transportasi). Faktor ini meliputi persepsi proses penggunaan JKN serta ada atau tidaknya akomodasi untuk memanfaatkan JKN. Indikator pertama terkait persepsi kemudahan proses penggunaan JKN. Berdasarkan Tabel 1, menunjukkan bahwa tidak terdapat perbedaan antara ketersediaan akomodasi pada kelompok mahasiswa kesehatan dan kelompok mahasiswa non kesehatan. Pada kelompok mahasiswa kesehatan, yang menyatakan bahwa memiliki ketersediaan akomodasi untuk memanfaatkan JKN sebesar $68 \%$, sedangkan sisanya sebesar $32 \%$ menyatakan bahwa tidak tersedia akomodasi untuk memanfaatkan JKN. Sementara itu pada kelompok mahasiswa non kesehatan, terdapat $63 \%$ responden menyatakan memiliki ketersediaan akomodasi untuk memanfaatkan JKN dan $37 \%$ sisanya menyatakan tidak tersedia akomodasi untuk memanfaatkan JKN.

Kondisi mahasiswa terkait ketersediaan akomodasi (transportasi) memengaruhi aksesibilitas mahasiswa terhadap JKN. Jarak dan ketersediaan akomodasi berhubungan dengan pemanfaatan pelayanan kesehatan (Alfian, 2000). Ketersediaan akomodasi tidak hanya terkait transportasi pribadi, namun juga ketersediaan transportasi umum yang tersedia. Sebagian besar pada kedua kelompok ini memiliki ketersediaan akomodasi, namun masih terdapat mahasiswa yang mengaku tidak memiliki akomodasi untuk mendukung aksesibilitasnya terhadap JKN.

Indikator kedua adalah persepsi proses penggunaan JKN. Berdasarkan Tabel 1, menunjukkan bahwa terdapat perbedaan antara persepsi kemudahan proses penggunaan JKN pada kelompok mahasiswa kesehatan dan kelompok mahasiswa non kesehatan. Bagi yang sudah memanfaatkan, pada kelompok mahasiswa kesehatan, yang menyatakan bahwa penggunaan JKN tergolong mudah sebesar $26 \%$, sedangkan sebesar $23 \%$ menyatakan bahwa penggunaan JKN tergolong sulit, dan $51 \%$ sisanya belum pernah memanfaatkan. Sementara itu pada kelompok mahasiswa non kesehatan, terdapat $17 \%$ responden menyatakan penggunaan JKN tergolong mudah, $6 \%$ menyatakan penggunaan JKN tergolong sulit dan sisanya $77 \%$ belum pernah memanfaatkan.

Secara umum, sebagian besar dari kedua kelompok mengaku bahwa proses penggunaan JKN termasuk mudah. Namun, masih terdapat beberapa mahasiswa yang merasa bahwa menggunakan JKN itu sulit di kedua kelompok tersebut.

Variabel keempat adalah Affordability (keterjangkauan). Faktor ini terkait dengan keterjangkauan besaran biaya iuran JKN. Indikator pertama yaitu terkait persepsi keterjangkauan biaya. Berdasarkan Tabel 1 menunjukkan bahwa terdapat perbedaan antara persepsi keterjangkauan biaya iuran program JKN pada kelompok mahasiswa kesehatan dan kelompok mahasiswa non kesehatan. Pada kelompok mahasiswa kesehatan, yang menyatakan bahwa biaya iuran program JKN terjangkau sebesar $65 \%$, sedangkan sisanya 
sebesar $35 \%$ menyatakan bahwa biaya iuran program JKN tidak terjangkau. Sementara itu pada kelompok mahasiswa non kesehatan, terdapat $38 \%$ menyatakan biaya iuran program JKN terjangkau dan $62 \%$ sisanya menyatakan biaya iuran program JKN tidak terjangkau.

Dari perhitungan diatas terlihat jelas perbedaan keterjangkauan biaya program JKN pada kelompok mahasiswa kesehatan dan kelompok mahasiswa non kesehatan. Pada mahasiswa kesehatan, penilaian terbesar menunjukkan bahwa biaya iuran program JKN terjangkau. Berbeda halnya dengan kelompok mahasiswa non kesehatan yang sebagian besar penilaiannya menyatakan bahwa biaya iuran program JKN tidak terjangkau. Berdasarkan penelitian yang dilakukan oleh Indryani (2015), faktor biaya berhubungan dengan pemanfaatan pelayanan kesehatan. Besaran biaya yang dikeluarkan, menjad masukan pertimbangan untuk menentukan keputusan dalam memanfaatkan suatu pelayanan kesehatan. Keputusan tersebut dipengaruhi oleh besaran kemampuan yang dimiliki.

Variabel kelima yaitu Appropriateness (ketepatan). Variabel Appropriateness meliputi persepsi ketepatan berjalannya program JKN serta kepuasan terhadap program JKN. Indikator pertama yaitu persepsi ketepatan program JKN. Indikator yang digunakan dalam penilaian ketepatan JKN ini terkait ketepatan pelaksanaan program JKN baik terkait manfaat, prinsip JKN dan keefektifan pelaksanaan JKN dalam program kesehatan. Berdasarkan Tabel 1, menunjukkan bahwa terdapat perbedaan antara persepsi ketepatan program JKN pada kelompok mahasiswa kesehatan dan kelompok mahasiswa non kesehatan. Pada kelompok mahasiswa kesehatan, yang menyatakan bahwa program JKN telah berjalan dengan tepat sebesar $22 \%$, sedangkan sisanya sebesar $78 \%$ menyatakan bahwa program JKN tidak berjalan dengan tepat. Sementara itu pada kelompok mahasiswa non kesehatan, terdapat $15 \%$ responden menyatakan program JKN telah berjalan dengan tepat dan $85 \%$ sisanya menyatakan program JKN tidak berjalan dengan tepat.

Kedua kelompok mahasiswa memiliki kesamaan yakni dengan persentase terbesar menunjukkan persepsi program JKN yang tidak berjalan dengan tepat. Persepsi ini menunjukkan bahwa masih terdapat mahasiswa yang menilai berjalannya program JKN belum optimal dan perlu adanya perbaikan. Persepsi adalah proses bagaimana seseorang menyeleksi, mengatur, dan menginterpretasikan masukanmasukan informasi untuk menciptakan gambaran keseluruhan yang berarti (Kotler, 1993). Pada hal ini dapat digambarkan bahwa mahasiswa mengolah masukan-masukan informasi yang ia terima terkait ketepatan berjalannya program JKN, sehingga menghasilkan suatu penilaian.

Indikator kedua adalah kepuasan terhadap program JKN. Berdasarkan Tabel 1, menunjukkan bahwa terdapat perbedaan antara kepuasan program JKN pada kelompok mahasiswa kesehatan dan kelompok mahasiswa non kesehatan. Bagi yang sudah memanfaatkan pada kelompok mahasiswa kesehatan, yang menyatakan puas terhadap program JKN sebesar $20 \%$, sedangkan sebesar $30 \%$ menyatakan bahwa responden tidak puas, dan $50 \%$ sisanya belum pernah memanfaatkan. Sementara itu pada kelompok mahasiswa non kesehatan, terdapat $15 \%$ responden menyatakan puas terhadap program JKN dan $8 \%$ menyatakan tidak puas terhadap program JKN, serta $77 \%$ sisanya belum memanfaatkan JKN. Besaran tingkat kepuasan pasien berhubungan dengan kualitas pelayanan kesehatan yang digunakan (Saputro, 2015). Belum optimalnya penilaian kepuasan oleh mahasiswa menggambarkan bahwa mahasiswa merasa kualitas program JKN belum optimal.

\section{SIMPULAN}

Kesimpulan berdasarkan hasil analisis yang telah dilakukan yaitu adanya perbedaan aksesibilitas antara kelompok mahasiswa kesehatan dan kelompok mahasiswa non kesehatan strata S-1 Universitas Airlangga terkait aspek pengetahuan, kedekatan dengan fasilitas kesehatan yang menerima JKN, persepsi kepentingan $\mathrm{JKN}$, kepesertaan $\mathrm{JKN}$, riwayat pemanfaatan JKN, kepesertaan JKN, kemudahan proses penggunaan JKN, keterjangkauan biaya program JKN, dan kepuasan program JKN. Sedangkan aspek yang tidak memiliki perbedaan pada kelompok mahasiswa kesehatan dan kelompok mahasiswa non kesehatan adalah kemudahan mendapatkan informasi, ketersediaan akomodasi, serta persepsi ketepatan program JKN. Saran dari penelitian ini yakni perlu adanya sosialisasi terkait pentingnya kepesertaan JKN dan pentingnya memperoleh manfaat JKN. Selain itu perlu adanya kerja sama antara fakultas, orangtua mahasiswa dan mahasiswa terkait pemanfaatan JKN untuk meningkatkan aksesibilitas JKN. Saran tersebut juga mendukung keberlangsungan program JKN di masa yang akan datang. Implikasi dari saran tersebut adalah menghambat berjalannya program JKN

\section{DAFTAR PUSTAKA}

Alfian, A. 2000. Beberapa Faktor yang Berhubungan dengan Pemanfaatan Pelayanan Kesehatan oleh Peserta JPKM di Kecamatan Patebon Kabupaten Kenda. Semarang: Universitas Diponegoro.

Amalina, R., Respati, \& Budiman. 2015. Tingkat Pengetahuan Jaminan Kesehatan Nasional Peserta Badan Penyelenggara Jaminan Sosial Kesehatan di Puskesmas Plered Kabupaten Purwakarta Tahun 2015.

BPJS Kesehatan. 2017. BPJS Kesehatan. [Online] Available at: HYPERLINK "https://bpjs-kesehatan. go.id" https://bpjs-kesehatan.go.id [Accessed 26 Mei 2017].

Cahyani, N.M.E. 2015. Tahap Adopsi Inovasi Pimpinan Badan Usaha dalam Kepesertaan Jaminan Kesehatan Nasional. Jember: Universitas Jember. 
Dimantri, C.N. 2017. Akseptabilitas Program Jaminan Kesehatan Nasional pada Mahasiswa dan Orang Tua Mahasiswa. Fakultas Kesehatan Masyarakat.

Kementerian Pendidikan dan Kebudayaan. 2015. Perkembangan Pendidikan Tinggi Tahun 1999/2000-2013/2014. Jakarta: Pusat Data dan Statistik Pendidikan dan Kebudayaan.

Kotler, P. 1993. Edisi Keenam Manajemen Pemasaran (Analisis, Perencanaan, Implementasi, dan Pengendalian). Erlangga.

Laksono, D. et al. 2016. Aksesibilitas Pelayanan Kesehatan di Indonesia. Yogyakarta: PT Kanisius.

Levesque, Frederic, J., Harris, F. \& Rus. 2013. Patientcentred Access to Health Care: Conceptualising Access at the Interface of Health Systems and Populations. International Journal for Equity in Health.

Masita, A., Yuniar, \& Lisnawaty. 2015. Faktor-Faktor yang Berhubungan Dengan Pemanfaatan Kesehatan Pada Masyarakat Desa Tailandu di Wilayah Puskesmas Kanapa-Napa Kecamatan
Mawasangka Kabupaten Buton Tengah Tahun 2015.

Republik Indonesia. 2004. Undang-Undang No. 40 Tahun 2004 Tentang Sistem Jaminan Sosial Nasional. Jakarta: Republik Indonesia Republik Indonesia.

Republik Indonesia. 2013. Peraturan Menteri Kesehatan Nomor 71 Tahun 2013 tentang Pelayanan Kesehatan pada Jaminan Kesehatan Nasional. Jakarta: Republik Indonesia Republik Indonesia.

Saputro, A.D. 2015. Hubungan Kualitas Pelayanan Kesehatan Dengan Kepuasan Pasien Rawat Jalan Tanggungan BPJS di Rumah Sakit Bethesda Yogyakarta. Surakarta: Universitas Surakarta.

Sarwono, J. 2017. Metode Riset Online. [Online] Available at: HYPERLINK "http://www. jonathansarwono.info/artikel/online.pptx" http:// www.jonathansarwono.info/artikel/online.pptx [Accessed 29 Juli 2017].

Widhiastuti, I.A.P., Januraga, P.P. \& Wirawan, D.N., 2015. Hubungan Persepsi Manfaat dengan Kepesertaan JKN. 3. 